\title{
Barium isotopes in cold-water corals
}

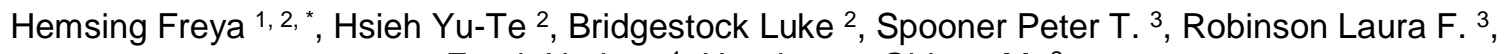 \\ Frank Norbert ${ }^{1}$, Henderson Gideon M. ${ }^{2}$
}

\author{
${ }^{1}$ Heidelberg Univ, Inst Environm Phys, Neuenheimer Feld 229, D-69120 Heidelberg, Germany. \\ 2 Univ Oxford, Dept Earth Sci, South Parks Rd, Oxford OX1 3AN, England. \\ 3 Univ Bristol, Sch Earth Sci, Queens Rd, Bristol BS8 1RJ, Avon, England.
}

* Corresponding author : Freya Hemsing, email address : freya.hemsing@iup.uni-heidelberg.de

\begin{abstract}
:
Recent studies have introduced stable $\mathrm{Ba}$ isotopes $(\delta 138 / 134 \delta 138 / 134 \mathrm{Ba})$ as a novel tracer for ocean processes. Ba isotopes could potentially provide insight into the oceanic $\mathrm{Ba}$ cycle, the ocean's biological pump, water-mass provenance in the deep ocean, changes in activity of hydrothermal vents, and land-sea interactions including tracing riverine inputs. Here, we show that aragonite skeletons of various colonial and solitary coldwater coral (CWC) taxa record the seawater (SW) Ba isotope composition. Thirty-six corals of eight different taxa from three oceanic regions were analysed and compared to $\delta 138 / 134 \delta 138 / 134 \mathrm{Ba}$ measurements of colocated seawater samples. Sites were chosen to cover a wide range of temperature, salinity, Ba concentrations and $\mathrm{Ba}$ isotope compositions. Seawater samples at the three sites exhibit the well-established anti-correlation between $\mathrm{Ba}$ concentration and $\delta 138 / 134 \delta 138 / 134 \mathrm{Ba}$. Furthermore, our data set suggests that $\mathrm{Ba} / \mathrm{Ca}$ values in CWCs are linearly correlated with dissolved $[\mathrm{Ba}]$ in ambient seawater, with an average partition coefficient of $\mathrm{DCWC} / \mathrm{SW}=1.8 \pm 0.4$ (2SD). The mean isotope fractionation of $\mathrm{Ba}$ between seawater and CWCs $\triangle 138 / 134 \mathrm{BaCWC}-\mathrm{SW}$ is $-0.21 \pm 0.08 \%$ (2SD), indicating that CWC aragonite preferentially incorporates the lighter isotopes. This fractionation likely does not depend on temperature or other environmental variables, suggesting that aragonite CWCs could be used to trace the $\mathrm{Ba}$ isotope composition in ambient seawater. Coupled $[\mathrm{Ba}]$ and $\delta 138 / 134 \delta 138 / 134 \mathrm{Ba}$ analysis on fossil CWCs has the potential to provide new information about past changes in the local and global relationship between [Ba] and $\delta 138 / 134 \delta 138 / 134 B a$ and hence about the operation of the past global oceanic Ba cycle in different climate regimes.
\end{abstract}

\section{Highlights}

First detailed study of $\mathrm{Ba}$ isotope fractionation in modern cold-water corals. Eight genera from the Atlantic and Southern Oceans were analysed. Constant fractionation between coral aragonite and seawater of -0.21 $\pm 0.08 \%$ (2SD). Ba isotopes in cold-water corals have the potential to trace past seawater $\delta^{138 / 134} \mathrm{Ba}$. Combined $\mathrm{Ba} / \mathrm{Ca}$ and isotope analysis can reconstruct past changes in oceanic $\mathrm{Ba}$ cycle.

Keywords : barium isotope fractionation, cold-water corals, calibration, $\mathrm{Ba} / \mathrm{Ca}$, paleoceanography 


\section{Introduction}

Aragonitic scleractinian cold-water corals (CWC) are distributed throughout the global oceans in waters ranging from just a few meters to abyssal depths of several thousand meters (Roberts et al., 2006). In contrast to traditional paleoceanographic archives such as sediment cores, reconnaissance and precise dating of CWCs is performed by ${ }^{14} \mathrm{C}$ and U-series dating (Mangini et al., 1998; Cheng et al., 2000; Douville et al., 2010; Margolin et al., 2014; Spooner et al., 2016). With linear extension rates of several mm/a (e.g. Mortensen, 2001; Orejas et al., 2008) oceanic changes on centennial, decadal, yearly or even seasonal time scales can be elucidated from geochemical and isotope tracers in aragonite CWC skeletons. Despite this advantage, only a small number of paleoceanographic tracers have been established successfully and applied in CWCs (Robinson et al., 2014). For example, temperature, state of ventilation and water-mass provenance have been retrieved from various elemental and isotope tracers (Robinson et al., 2014). However, biological factors, so-called 'vital effects', often alter some elemental and isotope systems, e.g. $\delta^{13} \mathrm{C}, \delta^{18} \mathrm{O}$ or $\mathrm{Li} / \mathrm{Ca}$, limiting their use as oceanic tracers (Adkins et al., 2003; Rollion-Bard et al., 2009; Raddatz et al., 2013).

Barium has an enigmatic oceanic chemistry that has been studied for many years. The nutrient-like distribution of dissolved $\mathrm{Ba}$ in seawater, $[\mathrm{Ba}]_{\mathrm{sw}}$, is closely correlated with silicate and alkalinity $\left(\mathrm{Si}(\mathrm{OH})_{4}\right)$ (Chow and Goldberg, 1960; Wolgemuth and Broecker, 1970; Jeandel et al., 1996). But numerous studies suggested that the oceanic Ba cycle is not directly linked to the silicate or carbonate cycle (Bishop, 1988; Monnin et al., 1999). While regenerative dissolved Ba enriches deep ocean concentrations, its removal in the upper ocean is attributed to the precipitation of barite $\left(\mathrm{BaSO}_{4}\right)$, even though seawater is mostly under-saturated in $\mathrm{BaSO}_{4}$. This behaviour can possibly be explained by the decay of organic matter in settling particles releasing $\mathrm{Ba}$ and/or $\mathrm{SO}_{4}{ }^{2-}$ into a microenvironment until a $\mathrm{BaSO}_{4}$-saturation is reached (Dehairs et al., 1980; Bishop, 1988; Paytan and Griffith, 2007; Horner et al., 2017).

A new-found ability to precisely measure naturally occurring fractionation between Ba isotopes enables further insight to be gained into the processes controlling the Ba cycle in the ocean. The isotope composition of $\mathrm{Ba}$ is defined with reference to the SRM NIST 3104a standard as

$\delta^{138 / 134} \mathrm{Ba}_{\text {NIST3104a }}=\left(\left({ }^{138} \mathrm{Ba} /{ }^{134} \mathrm{Ba}_{\text {sample }}\right) /\left({ }^{138} \mathrm{Ba} /{ }^{134} \mathrm{Ba}_{\text {NIST3104a }}\right)-1\right) \times 1000$ 
which we abbreviate to $\delta^{138 / 134} \mathrm{Ba}$. Recent $\mathrm{Ba}$ isotope studies have focussed on fractionation processes during experimental precipitation of $\mathrm{BaCO}_{3}, \mathrm{BaSO}_{4}$ and $\mathrm{BaMn}\left[\mathrm{CO}_{3}\right]_{2}$ (von Allmen et al., 2010; Böttcher et al., 2012; Mavromatis et al., 2016; van Zuilen et al., 2016), in igneous rocks (Miyazaki et al., 2014; Nan et al., 2015), in sediments and soils (Bridgestock et al., 2018; Bullen and Chadwick, 2016), and in seawater (Horner et al., 2015; Cao et al., 2016; Bates et al., 2017; Hsieh and Henderson, 2017). During barite, $\mathrm{BaCO}_{3}$ and $\mathrm{BaMn}\left[\mathrm{CO}_{3}\right]_{2}$ precipitation experiments, the solid phase preferentially incorporates the lighter isotopes, leaving the solution relatively heavy in Ba isotopes (von Allmen et al., 2010; Böttcher et al., 2012; van Zuilen et al., 2016). Upper ocean barite formation and its dissolution in the deep ocean lead to an inverse profile for Ba isotopes compared to dissolved $\mathrm{Ba}$ concentration, with light $\mathrm{Ba}$ isotope compositions in the deep ocean and heavier isotope compositions in surface waters (e.g. Horner et al., 2015). Further studies on Ba isotopes highlighted the potential to provide insight into the oceanic Ba cycle, the ocean's biological pump, deep water-mass provenance (Bates et al., 2017; Horner et al., 2015), riverine inputs (Cao et al., 2016), and possibly other inputs from sediment and/or hydrothermal inputs (Hsieh and Henderson, 2017). To investigate past changes in these processes, CWCs could be a promising archive.

Over the years, several studies have shown that, the $\mathrm{Ba} / \mathrm{Ca}$ ratio in foraminifera and calcitic corals reflects Ba concentrations in ambient seawater $[\mathrm{Ba}]_{\mathrm{sw}}$ (LaVigne et al., 2011; Lea and Boyle, 1993). Recently, calibration of the $\mathrm{Ba} / \mathrm{Ca}$ in aragonitic CWCs to reconstruct past $[\mathrm{Ba}]_{\mathrm{sw}}$ has been a focus of research (Anagnostou et al., 2011; LaVigne et al., 2016; Spooner, 2016). However, only one study has included an assessment of Ba isotopes in coralline carbonate (Pretet et al., 2016). That study measured $\mathrm{Ba}$ isotopes in cultured tropical aragonitic scleractinian corals grown in Mediterranean seawater, revealing a variable fractionation (see EQ.2) between seawater and cultured coralline aragonite ranging from $-0.02 \%$ (Acropora sp. and Porite sp.) to $-0.35 \%$ (Stylophora sp. and Montipora sp.). The Ba isotope composition of natural CWCs was also reported; two Lophelia pertusa (L. pertusa) samples from the Norwegian shelf were analysed and found to have $\delta^{138 / 134} \mathrm{Ba}$ values of $0.25 \pm 0.11 \%$ and $0.3 \pm$ $0.11 \%$.

In this study we present the first detailed study of $\delta^{138 / 134} \mathrm{Ba}$ in natural CWCs in comparison to that of the seawater in which they grew. The data set includes thirty-six well-characterised aragonitic 
scleractinian specimens from eight different taxa, both solitary and colonial, recovered from three sites: the North Atlantic, the Equatorial Atlantic, and the Drake Passage. The samples cover a wide range of environmental conditions, Ba concentrations, and seawater Ba isotope compositions. This allows for a systematic assessment of the Ba isotope fractionation during coral growth and the use of CWCs as an archive for past seawater $\delta^{138 / 134} \mathrm{Ba}$.

\section{Materials and analytical methods}

\subsection{Samples}

Thirty-six CWCs and ambient seawater samples from three ocean regions were selected for Ba isotope analysis. The locations were: south of Iceland in the North Atlantic (Reykjanes Ridge and Hafadjup), in the Equatorial Atlantic (Carter Seamount), and in the Drake Passage (Burdwood Bank) (Tab.1). They were chosen to cover a wide range of temperature and salinity (e.g. T: $2-11.5^{\circ} \mathrm{C} ; \mathrm{S}: 34.29-35.32 \mathrm{psu}$ ), Ba concentrations and Ba isotope compositions (Fig. 1, $2 \&$ 7, supplementary material). Eight different colonial and solitary aragonite scleractinian coral taxa (identified to either genus or species level) of living or young (less than 1000 a) CWCs were sampled: Lophelia pertusa (L. pertusa), Madrepora oculata (M. oculata), Desmophyllum dianthus (D. dianthus), Balanophyllia sp., Caryophyllia sp., Dasmosmillia sp., Flabellum sp. and Javania sp. (supplementary material). Corals off Iceland were collected during the ICECTD cruise in 2012 (Frank et al., 2012) using the ROV Victor 6000 (provided by IFREMER). Simultaneously, seawater samples $(125 \mathrm{ml})$ were directly filled (unfiltered) into acid cleaned PEP bottles by the ROV. They were stored at room temperature. Three months prior to Ba isotope analysis, seawater samples were acidified to a $\mathrm{pH}$ of 1.5 by adding purified, concentrated $\mathrm{HCl}$. Therefore, in these samples total dissolvable Ba concentrations and isotope compositions are analysed. Equatorial Atlantic samples from Carter Seamount were recovered during the JC094 cruise in 2013 (Robinson, 2014; Spooner et al., 2016). The corals were collected by the ROV Isis. Ambient seawater samples are from CTD station 2 and were analysed by Bates et al., 2017. In contrast to seawater samples from Iceland and the Drake Passage, Equatorial Atlantic samples were filtered with $0.4 \mu \mathrm{m}$ Acropak cartridge filters before acidification. CWCs from Burdwood Bank in the Drake Passage were collected 
in 2011 during cruise NBP1103, using a small basket dredge and trawls (Chen et al., 2015; Margolin et al., 2014; Robinson and Waller, 2011). Depths and coordinates given here are the average for each retrieval event. Seawater samples are from CTD station 21 and were taken unfiltered in Niskin bottles, acidified with $4 \mathrm{ml}$ concentrated $\mathrm{HCl}$ and stored at room temperature. As Burdwood Bank is positioned north of the Subantarctic front an additional unfiltered seawater profile close to Sars Seamount between the Subantarctic and the Polar front was analysed (cruise NBP1103, station 100). Temperature and salinity were determined following Spooner et al. (2016). Further details regarding the coral samples are summarised in the supplementary material.

\subsection{Ba extraction and analysis}

All samples (corals and seawater), except for the seawater samples analysed by Bates et al., 2017 (CTD 2, cruise JC094), were prepared and analysed at the Earth Sciences Department of the University of Oxford. Ba isotopes, for both seawater and CWC samples, were measured on a thermal ionisation mass spectrometer (TIMS; Thermo Scientific Triton), using a ${ }^{137} \mathrm{Ba}-{ }^{135} \mathrm{Ba}$ double spike to correct for mass fractionation during the chemical procedure and instrumental analysis (Hsieh and Henderson, 2017). For seawater analyses, about $50 \mathrm{ml}$ of seawater was precisely weighed and spiked with a known quantity of the double spike. After an equilibration period of $24 \mathrm{~h}, 3 \mathrm{ml}$ of $0.9 \mathrm{M} \mathrm{Na}_{2} \mathrm{CO}_{3}$ solution was added to co-precipitate $\mathrm{Ba}$ with $\mathrm{CaCO}_{3}$. The precipitate was centrifuged and cleaned with MilliQ water. After dissolving the precipitate in $\mathrm{HCl}$, column separation was applied twice using the cation exchange resin AG50-X8 (200 - 400mesh) to purify Ba from the matrix elements (Table S2 and S3 in supplementary material of (Bridgestock et al., 2018) after (Horner et al., 2015; Foster et al., 2004; Nan et al., 2015)). To remove organics leached from the resin, $7.5 \mathrm{M} \mathrm{HNO}_{3}$ and $9.8 \mathrm{M} \mathrm{H}_{2} \mathrm{O}_{2}$ were alternately added to the samples and evaporated. This procedure was repeated three times.

CWC samples were rinsed with fresh water on-board ship. Living corals were bleached to remove external organic tissue and washed again in fresh water. All corals were dried and stored at room temperature until analysis. The cleaning procedure was adapted from Copard et al. (2010) and Pretet et al. (2016). CWCs were thoroughly mechanically cleaned using a dremel tool, removing FeMn-coatings 
and organic residues. To remove any further contamination coral pieces were then washed three times in MilliQ water in acid cleaned Teflon vials and leached in very dilute $\mathrm{HCl}$. Leaching was performed by covering the sample with MilliQ water and adding drops of $2 \mathrm{M} \mathrm{HCl}$ until small bubbles could be seen around the aragonite. Leaching lasted for five minutes before rinsing three times with MilliQ water again. Afterwards, samples were dried and weighed (45-70 mg). The sample size was chosen to have more than $300 \mathrm{ng}$ of $\mathrm{Ba}$ for isotope measurements. Although small intra-skeletal variabilities of around $11 \%$ were observed for the aragonitic CWC species $L$. pertusa between theca walls and centres of calcification (Raddatz et al., 2016), sample size tests on two Desmophyllum (5-40 mg) showed that different sizes did not affect the obtained $\mathrm{Ba} / \mathrm{Ca}$ result significantly and tended towards better reproducibilities for larger CWC pieces (Spooner, 2016). Therefore, the sample size used here potentially reduces the small influence of intra-skeletal $\mathrm{Ba} / \mathrm{Ca}$ variability. Coral pieces were dissolved in $5 \mathrm{ml} 7.5 \mathrm{M} \mathrm{HNO}_{3}$ and spiked with a known quantity of ${ }^{137} \mathrm{Ba}^{135}{ }^{135} \mathrm{Ba}$ double spike (Hsieh and Henderson, 2017). To ensure spike equilibration, samples were heated to $90-100^{\circ} \mathrm{C}$ for at least $12 \mathrm{~h}$ following spike addition. Coral samples were subsequently dried down, dissolved in $3 \mathrm{M} \mathrm{HCl}$, dried again and redissolved in $1 \mathrm{ml} 3 \mathrm{M} \mathrm{HCl}$. Ba purification by cation exchange chromatography followed the procedure for seawater samples (Table S2 and S3 in supplementary material of (Bridgestock et al., 2018)).

At least two total procedural blanks were determined alongside each batch of samples processed through the chemical separation procedure. For seawater samples these were between 0.19 and $1.6 \mathrm{ng}(\mathrm{n}=4)$, in samples. Therefore, no blank correction was applied to either seawater or coral samples. Purified samples were dissolved in $1-2 \mu \mathrm{l} 2 \mathrm{M} \mathrm{HCl}$ and loaded on a previously outgassed single $\mathrm{Re}$ filament, adding $1-2 \mu 1 \mathrm{Ta}_{2} \mathrm{O}_{5}-\mathrm{H}_{3} \mathrm{PO}_{4}$ activator (Hsieh and Henderson, 2017). To stabilise the ion beams during the analysis the activator was loaded on the filament prior to the samples.

167 For coral samples, typical ion beams during the analysis on the TIMS were $8-10 \mathrm{~V}$ for ${ }^{138} \mathrm{Ba}^{+}$. Seawater 
Seven Faraday cups simultaneously detected the masses $138^{+}, 137^{+}, 136^{+}, 135^{+}, 134^{+} 140^{+}$and $139^{+}$,

170

171

172

173

174

175 with the latter reflecting ${ }^{140} \mathrm{Ce}^{+}$and ${ }^{139} \mathrm{La}^{+}$, which were monitored to account for possible isobaric interferences on ${ }^{136} \mathrm{Ba}$ and ${ }^{138} \mathrm{Ba}$. No $140^{+}$and $139^{+}$signals were detected above background during any analysis. A single analysis consisted of 54 blocks, each containing 10 isotope ratio measurements, with a measurement integration time of $8.4 \mathrm{~s}$. To monitor the electronic baseline the X-Symmetry of the instrument was adjusted to divert the ion beams before each block. Blank analyses were measured for 20 - 30 blocks. To correct for instrumental mass bias using the double spike composition, all raw data were processed offline (Hsieh and Henderson, 2017). The isotope analysis together with the known spike mass also provide Ba concentration measures.

The standard JCp-1, consisting of powdered coral (Okai et al., 2002), was also analysed three times. It was prepared in the same way as CWCs samples but without the mechanical and chemical cleaning steps.

\section{Results}

\subsection{Reproducibility}

Repeat analyses of the SRM NIST 3104a standard using similar beam sizes for seawater samples lead to a long-term external reproducibility of $\pm 0.03 \%$ (2SD; (Bridgestock et al., 2018; Hsieh and Henderson, 2017)). Repeat analysis of the coral standard JCp-1 yielded a $\delta^{138 / 134} \mathrm{Ba}$ of $0.25 \pm 0.03 \%$ ( $2 \mathrm{SD}, \mathrm{n}=3$ ), which is within error of analyses in two other laboratories with values of $0.29 \pm 0.03 \%$ o (Horner et al., 2015) and $0.26 \pm 0.1 \%$ (Pretet et al., 2016). Several duplicates of seawater and coral samples confirm the reproducibility of $\pm 0.03 \%$ (supplementary material). Bridgestock et al., (2018) and Hsieh and Henderson (2017), studies also undertaken at University of Oxford, further verify this level of reproducibility for seawater and sediment samples. Two analyses were discarded because they yielded a larger internal standard error for $\delta^{138 / 134} \mathrm{Ba}$ than the standard reproducibility $( \pm 0.03 \%)$ and were considered unreliable. Both of these samples were subsequently successfully re-analysed.

The reproducibility for the Ba concentration of the repeated coral standard (JCp-1) and seawater sample measurements (Bridgestock et al., 2018; Hsieh and Henderson, 2017) was \pm 2 to 3\% (1SD), which is presumably dominated by weighing uncertainties $(2-3 \%)$ and taken as the uncertainty for $\mathrm{Ba}$ 
concentrations of corals and seawater measured in this study. Converting the concentration to $\mathrm{Ba} / \mathrm{Ca}$ by assuming a Ca concentration of $40 \%$ per mass of the coral (Roberts et al., 2009), the average $\mathrm{Ba} / \mathrm{Ca}$ in JCp-1 obtained in this study, $7.94 \pm 0.22 \mu \mathrm{mol} / \mathrm{mol}(\mathrm{n}=3 ; 3 \% 2 \mathrm{SD}$ ), is within uncertainty of previous studies (e.g. $7.465 \pm$ 0.655; (Hathorne et al., 2013)). For seawater samples a Ca concentration of 10.3 mmol/kg (Henderson and Henderson, 2009) was taken to convert Ba concentrations into $\mathrm{Ba} / \mathrm{Ca}$ sw values.

\section{$3.2 \delta^{138 / 134} \mathrm{Ba}$ in seawater profiles}

The seawater profile from the Burdwood Bank in the Drake Passage shows the established anticorrelation between $[\mathrm{Ba}]_{\mathrm{sw}}$ and $\delta^{138 / 134} \mathrm{Ba}$ (Fig. 1; (Bridgestock et al., 2018; Hsieh and Henderson, 2017; Bates et al., 2017; Pretet et al., 2016; Horner et al., 2015)). Note, that seawater data from the South China Seas were reported to exhibit a different correlation between $[\mathrm{Ba}]_{s w}$ and $\delta^{138 / 134} \mathrm{Ba}$ (Cao et al., 2016) and were therefore excluded in the compilation of published data (Fig. 1). [Ba $]_{\mathrm{sw}}$ is $55.2 \mathrm{nmol} / \mathrm{kg}$ in surface waters and increases to $102 \mathrm{nmol} / \mathrm{kg}$ at $2250 \mathrm{~m}$ water depth. The isotope composition of $\mathrm{Ba}$ decreases with depth from $0.5 \%$ to $0.25 \%$.

Tropical Atlantic water samples measured and described in detail by Bates et al. (2017) (CTD 2, cruise JC094) show a similar distribution with Ba concentrations increasing from $37.9(11 \mathrm{~m})$ to $84.6 \mathrm{nmol} / \mathrm{kg}$ at $4512 \mathrm{~m}$ depth and $\delta^{138 / 134} \mathrm{Ba}$ decreasing from $0.57 \%$ to $0.31 \%$ (Fig. 1). Note, that Ba concentration for station CTD 2 were initially given in $\mathrm{nM}$ (Bates et al., 2017) and have been recalculated here to $\mathrm{nmol} / \mathrm{kg}$ by assuming a seawater density of $1.027 \mathrm{~kg} / \mathrm{l}$.

Seawater samples from south of Iceland, at Reykjanes Ridge and within Hafadjup basin, cover the depth range of 238 to $680 \mathrm{~m}$, coinciding with the depths of coral retrieval (Fig. 1). Over this depth interval both $[\mathrm{Ba}]_{\mathrm{sw}}$ and $\delta^{138 / 134} \mathrm{Ba}$ are nearly constant within uncertainties: $49.3-52.9 \mathrm{nmol} / \mathrm{kg}$ and $0.51-$ $0.53 \%$ respectively.

The seawater samples analysed in this study cover nearly the total range of presently available seawater $\delta^{138 / 134} \mathrm{Ba}$ and confirm published data (Fig. 2; (Bridgestock et al., 2018; Hsieh and Henderson, 2017; Bates et al., 2017; Pretet et al., 2016; Horner et al., 2015)). Isotope compositions of Ba from publications originally reporting in $\delta^{137 / 134} \mathrm{Ba}$ were converted to $\delta^{138 / 134} \mathrm{Ba}$ by multiplying by a factor of 1.3 (after 
Horner et al.; 2015). The closest seawater profiles were used to compare seawater $\delta^{138 / 134} \mathrm{Ba}$ with the coral analyses. To obtain $\delta^{138 / 134} \mathrm{Basw}$ at the water depths in which the analysed corals grew, the values of seawater samples at adjacent depths were linearly interpolated.

\section{$3.3 \mathrm{Ba} / \mathrm{Ca}$ in cold-water corals}

$\mathrm{Ba} / \mathrm{Ca}$ for corals varied between 7.5 and $16.3 \mu \mathrm{mol} / \mathrm{mol}$ (Fig. 3a, supplementary material), while seawater samples spanned 3.9 to $9.7 \mu \mathrm{mol} / \mathrm{mol}$ (Fig. 3a, supplementary material). Ba/Ca results of different discrete subsamples of some corals from the Equatorial Atlantic and the Drake Passage and analysis of JCp-1 (6.96 \pm 0.08 2SE, $n=13)$ were also carried out in the Bristol Isotope Group (Spooner, 2016). Accounting for analytical deviations between the laboratories seen in the JCp-1 analysis, the measurements of both laboratories agree for all subsampled corals, despite the use of two different measurement approaches. The double spike method with Ba purification used here, analysed on a TIMS, was compared to direct $\mathrm{Ba} / \mathrm{Ca}$ measurements of dissolved coral fragments using a ThermoFinnigan Element 2 ICP-MS (Spooner, 2016).

A linear least squares regression gives $\mathrm{Ba} / \mathrm{Ca}_{\mathrm{CwC}}=1.8( \pm 0.4,2 \mathrm{SE}) \mathrm{Ba} / \mathrm{Ca}$ sw $+0.7( \pm 2.6)$ with a correlation factor of $r^{2}=0.67$. Therefore, the overall partition coefficient $\mathrm{D}_{\mathrm{CWC} / \mathrm{sw}}$ (Ba) (i.e. $\left.\mathrm{Ba} / \mathrm{Ca} a_{\mathrm{Cw}} / \mathrm{BaCa}_{\mathrm{sw}}\right)$ observed is $1.8 \pm 0.4(2 \mathrm{SE})$. The partition coefficient calculated separately for each CWC in this study covers a range from 1.5 to 2.4.

\section{$3.4 \delta^{138 / 134} \mathrm{Ba}$ in cold-water corals}

CWCs of four different taxa were analysed from Burdwood Bank (Fig. 3b - 6, supplementary material). and three D. dianthus, with samples taken from depths ranging from 334 to $1829 \mathrm{~m}$. Isotope compositions $\delta^{138 / 134} \mathrm{Ba}$ are $0.24 \%$ in shallow corals and $0.03 \%$ in the deeper corals (Fig. 4), reflecting the decrease in seawater $\delta^{138 / 134} \mathrm{Ba}$ with depth. At each depth, coral $\delta^{138 / 134} \mathrm{Ba}$ values agree with each other within external reproducibility $( \pm 0.03 \%)$, regardless of species.

251 The fractionation of Ba between corals and seawater can be expressed by the isotope fractionation factor $\alpha=\mathrm{R}_{\mathrm{CWC}} / \mathrm{R}_{\mathrm{Sw}}$ or the enrichment factor 
with an external analytical $2 \mathrm{SD}$ of $\pm 0.04 \%$ propagated from the analytical $2 \mathrm{SD}$ of $\delta^{138 / 134} \mathrm{Ba}( \pm 0.03 \%$ ). Individual enrichment factors in CWCs from Burdwood Bank range from -0.19 to $-0.29 \%$ with an average of $-0.24 \pm 0.06 \%$. The uncertainty of the average is assumed to be the larger of either the propagated external reproducibility or the $2 \mathrm{SD}$ obtained when averaging over a number of corals.

Taxa analysed form Carter Seamount include two Dasmosillia sp., six Caryphyllia sp., and four Javania $s p$. covering water depths from 265 to $2318 \mathrm{~m}$. $\delta^{138 / 134} \mathrm{Ba}$ varies from 0.18 to $0.40 \%$ associated with enrichment factors of -0.16 to $-0.27 \%$, with a mean of $-0.19 \pm 0.07 \%$.

Corals analysed from Iceland only cover shallow water depths between 206 and 698m. Three species, six $D$. dianthus, five $L$. pertusa, and one $M$. oculata, show an isotope composition of $0.28-0.36 \%$. The enrichment $\Delta^{138 / 134} \mathrm{Ba}_{\mathrm{CwC}}$-sw between seawater and coral $\delta^{138 / 134} \mathrm{Ba}$ is -0.16 to $-0.24 \%$ also averaging to $-0.19 \pm 0.05 \%$

The fractionation $\Delta^{138 / 134} \mathrm{Ba}$ Cwc-sw between CWCs and seawater averaged over all locations and species is $-0.21 \pm 0.08 \%$ o $\left(2 \mathrm{SD} ; 2 \mathrm{SE}= \pm 0.01 \%\right.$ o $\left(\alpha_{\mathrm{Ba}}=0.99979 \pm 0.00008\right)($ Fig. 5$)$. Averaging for each species separately leads to a Ba fractionation between -0.17 and $-0.25 \%$ (Fig. 5 and supplementary material). The genus Balanophyllia sp. $(\mathrm{n}=5)$ shows the largest Ba fractionation of $-0.25 \pm 0.05 \%$ (2SD) while Javania sp. $(\mathrm{n}=4)$ fractionates Ba by only $-0.17 \pm 0.04 \%$. The two genera with the highest variability in $\Delta^{138 / 134} \mathrm{Ba}$ were $D$. dianthus $(\mathrm{n}=9)$ with values ranging from $-0.16 \%$ to $-0.28 \%$ and averaging $-0.22 \pm$ $0.08 \%$, and Caryophyllia sp. $(\mathrm{n}=8)$ covering a range of $-0.16 \%$ to $-0.27 \%$ and averaging $-0.21 \pm 0$. $07 \%$.

\section{Discussion}

\subsection{Constancy of $\mathrm{D}_{\mathrm{CwC} / \mathrm{sw}}(\mathrm{Ba})$}

The mean partition coefficient derived by a linear fit to all data is $\mathrm{D}_{\mathrm{CwC} / \mathrm{sw}}(\mathrm{Ba})=1.8 \pm 0.4$ (2SE, see Fig. 3a) covering a range from 1.5 to 2.4 for separate samples. These values are similar to those in previous studies (Anagnostou et al., 2011; Spooner, 2016). The study by Anagnostou et al., 2011 $\left(\mathrm{Ba} / \mathrm{Ca}_{\mathrm{CwC}}=1.4( \pm 0.3) \mathrm{Ba} / \mathrm{Ca}_{\mathrm{Sw}}+0( \pm 2)\right)$ did not reveal a significant correlation between the partition coefficient and seawater temperature, salinity or $\mathrm{pH}$. Spooner (2016) analysed possible environmental 
impacts on $\mathrm{D}_{\mathrm{Cwc} / \mathrm{sw}}(\mathrm{Ba})$ in more detail, confirming the findings of Anagnostou et al. (2011), and indicating that $\mathrm{D}$ is independent of seawater nutrient content $\left(\mathrm{PO}_{4}\right)$ and oxygen concentrations. Data in this study support the previous finding that incorporation of Ba into CWCs does not depend on seawater temperature (Fig. 7(a)), water depth, salinity, pH or nutrient content but seems to occur at a constant D value (Tab. A1 in supplementary material). Within the stated uncertainty of 0.4 , no clear inter-species or location effect is resolved. Analysis at higher precession and a considerably larger data set might resolve variations smaller than the resolution here. At the stated uncertainty of 0.4 , however, we consider D constant which favours the use of CWCs to reconstruct past oceanic Ba concentrations, with potential application to assess past biogeochemical cycling of $\mathrm{Ba}$ and/or ocean circulation.

\subsection{Constancy of $\Delta^{138 / 134} \mathrm{Bacwc}-\mathrm{sw}$}

With a mean enrichment factor $\Delta_{\mathrm{BaSO}_{4}}$-sw of $-0.21 \pm 0.08 \%$ (Fig. 5) all thirty-six coral samples analysed in this study are enriched in lighter Ba isotopes compared to ambient seawater (Fig. 4). The incorporation of lighter isotopes during carbonate formation is similar to other isotope systems such as Ca (e.g. Böhm et al., 2006; Fantle and DePaolo, 2007), Sr (e.g. Fietzke and Eisenhauer, 2006; Raddatz et al., 2013), Mg (e.g. Yoshimura et al., 2011) and Li (e.g. Marriott et al., 2004; Rollion-Bard et al., 2009). The most likely explanation for the fractionation is a kinetic effect combined with biological impacts (e.g. Böhm et al., 2006; DePaolo, 2004).

The offset towards light $\mathrm{Ba}$ isotopes during incorporation into a mineral phase is similar to that seen in limited previous studies. Pretet et al. (2016) analysed two L. pertusa from the Norwegian margin and found $\delta^{138 / 134} \mathrm{Ba}$ of $0.25 \pm 0.11 \%$ and $0.3 \pm 0.11 \%$, but without accompanying seawater measurements. The coral values in that study are, however, identical within uncertainties to North Atlantic corals from this study. Further analyses in Pretet et al. (2016) on cultured tropical aragonitic scleractinian corals showed a more variable fractionation than observed here, varying between $-0.02 \%$ (Acropora $s p$. and Porite sp.) and -0.38\%o (Stylophora sp. and Montipora sp.) (Fig. 6).

Previous inorganic precipitation experiments of $\mathrm{BaSO}_{4}$ and $\mathrm{BaMn}\left[\mathrm{CO}_{3}\right]_{2}$ showed a similar preference for incorporation of lighter isotopes, with a fractionation of $-0.33 \pm 0.04 \%$ and $-0.17 \pm 0.028 \%$ respectively (Fig. 6; (von Allmen et al., 2010; Böttcher et al., 2012)). Reported Ba isotope fractionation 
during $\mathrm{BaCO}_{3}$ precipitation is between $-0.25 \pm 0.028 \%$ (von Allmen et al., 2010) and $-0.07 \pm 0.04 \%$ o (Mavromatis et al., 2016). The fractionation observed for CWCs analysed in this study lies roughly in the middle of the fractionation range reported on precipitates or cultured aragonite tropical corals (Fig. 6; (von Allmen et al., 2010; Böttcher et al., 2012; Pretet et al., 2016)). Analysis of the relationship between $[\mathrm{Ba}]$ and $\delta^{138 / 134} \mathrm{Ba}$ in seawater also suggests that $\mathrm{Ba}$ isotopes incorporated into $\mathrm{BaSO}_{4}$ during precipitation in the water column are lighter than seawater, with $\Delta_{\mathrm{BaSO}_{4} \text {-sw }}=-0.28 \pm 0.10 \%$ (Horner et al., 2015) or -(0.4-0.5)\% (Bridgestock et al., 2018; Horner et al., 2017). The results in this study for coral aragonite are at the lower limit of this range.

At the precision of our measurements, there is no correlation between water temperature (between 2 and $12^{\circ} \mathrm{C}$ ) and $\mathrm{Ba}$ isotope fractionation $\left(\Delta^{138 / 134} \mathrm{Ba}\right)$ observed in this study (Fig. $7(\mathrm{~b})$, supplementary material). No previous study has assessed the temperature dependency of $\Delta^{138 / 134} \mathrm{Ba}$ on $\mathrm{CaCO}_{3}$ formation, although no temperature dependency of fractionation in laboratory grown $\mathrm{BaCO}_{3}$ precipitates was found (von Allmen et al., 2010). A possible effect of precipitation rates was observed for Ba fractionation into $\mathrm{BaCO}_{3}$ precipitates with a larger fractionation for slower precipitation rates. Transferring this observation to the higher variance seen in the cultured corals compared to the natural coral analysed in this study cannot explain the observed discrepancy. Known linear extension rates of the taxa analysed in this study span a wide range, from e.g. $0.5-3.1 \mathrm{~mm} / \mathrm{a}$ for $D$. dianthus and $5-26$ mm/a for L. pertusa (Gass and Roberts, 2006; Mortensen, 2001; Orejas et al., 2008), and no significant impact on Ba fractionation could be observed at the precision achieved in this study.

No substantial correlation between fractionation and nutrient availability $\left(\mathrm{PO}_{4}\right)$ could be observed (supplementary material). Analyses of other environmental factors like depth, $\mathrm{pH}$ and salinity provided no clear evidence for significant impacts on Ba fractionation (supplementary material). At the precision achieved here, there is also no influence of dissolved $\mathrm{Ba}$ concentration in seawater on $\mathrm{Ba}$ isotope fractionation (Fig. 7(c)).

Different species span a range of enrichment factors from $-0.17 \%$ (Javania sp.) to $-0.25 \%$ o (Balanophyllia sp.) (Fig. 5). However, this possible inter-species difference is barely resolved at the $0.03 \%$ level of our analytical uncertainty and compounded by the possibility of regional variations. All species lie well within the $2 \mathrm{SD}(0.08 \%)$ of the average fractionation between seawater and CWCs 
$337\left(\Delta^{138 / 134} \mathrm{Ba}_{\mathrm{CwC}} \mathrm{sw}=-0.21 \%\right)$. The isotope offset of CWCs at the Drake Passage may also be subtly 338 different from that in the Atlantic (Fig. 4), but again any difference is very close to analytical uncertainty 339 and lies well within the $2 \mathrm{SD}$ of the average fractionation. It is possible that species or local effects may 340 become apparent with future higher precision or a significant larger data set, but at the stated uncertainty 341 of $0.08 \%$ the offset between seawater and CWC Ba isotopes is constant.

\section{$4.3 \delta^{138 / 134}$ Ba: a new proxy for paleoceanography}

Recent studies have demonstrated a strong linear relationship between $\delta^{138 / 134} \mathrm{Ba}$ and $[\mathrm{Ba}]$ in seawater (Bates et al., 2017; Hsieh and Henderson, 2017; Horner et al., 2015; Bridgestock et al., 2018). Local deviations from this relationship could provide evidence for local inputs of $\mathrm{Ba}$ with distinct isotope compositions. Variation in the nature of the global relationship may occur in the past, and would indicate changes in the global biogeochemical cycling of Ba through time. The fact that, within the uncertainties stated in this study, both $\mathrm{D}_{\mathrm{CWC} / \mathrm{sw}}(\mathrm{Ba})$ and $\Delta^{138 / 134} \mathrm{Ba}_{\mathrm{CWC}-\mathrm{sw}}$ are found to be constant for CWCs regardless of the growth environment suggests that measurements on fossil corals would allow reconstruction of the past ocean relationship between $\left[\mathrm{Ba}\right.$ and $\delta^{138 / 134} \mathrm{Ba}$. Analysis of coralline $\mathrm{Ba} / \mathrm{Ca}$ can provide information about the $[\mathrm{Ba}]$ of the water the coral grew in, with possible implications for changing productivity and/or water circulation. However, measurements of this parameter alone cannot provide information about local inputs of $\mathrm{Ba}$, nor possible changes in the whole oceanic Ba cycle but can be constrained by additional $\delta^{138 / 134} \mathrm{Ba}$ analyses. Thus, our observations suggest future applications regarding the reconstruction of the past marine $\mathrm{Ba}$ cycle using coupled $\mathrm{Ba} / \mathrm{Ca}$ and $\mathrm{Ba}$ isotope measurements in CWCs.

Based on the data presented here we can test the potential accuracy of seawater Ba reconstructions from CWCs. The constancy of both the elemental partition coefficient and isotope fractionation for Ba in combination with the safe assumption that the seawater Ca content remained similar on long timescales, enables reconstruction of past seawater $[\mathrm{Ba}]$ and $\delta^{138 / 134} \mathrm{Ba}$ from coral data. Within uncertainty the reconstructed linear correlation for seawater has slope and intersect values that are equal to the relationship directly measured in seawater samples (Fig. 8). 
To avoid the possibility of circular reasoning by using the same coral set to both define and test $\mathrm{D}_{\mathrm{CwC} / \mathrm{sw}}$ (Ba) and $\Delta^{138 / 134}$ Bacwc-sw to reconstruct seawater, we ran repeated Monte-Carlo cross validations splitting the data set in two halves. The cross validation was run 1000 times to assess the predictive capability of our calibration for $\mathrm{D}_{\mathrm{CwC} / \mathrm{sw}}(\mathrm{Ba})$ and $\Delta^{138 / 134} \mathrm{Ba}$ Cwc-sw (supplementary material). The distribution obtained confirms the results when using all thirty-six CWCs for both the elemental partition and isotope fractionation, and slope and y-intersect of the seawater $\delta^{138 / 134} \mathrm{Ba}-[\mathrm{Ba}]$ correlation. The average $\delta^{138 / 134} \mathrm{Ba}$ deviation of each reconstructed seawater value from the best-fit regression through the seawater observations is $0.03 \%$, indicating the expected uncertainty in future studies on past seawater reconstructions. This level of uncertainty is similar to the uncertainty of an individual $\mathrm{Ba}$ isotope analysis, suggesting that the range of values observed for the fractionation $\Delta^{138 / 134} \mathrm{Ba} \mathrm{C}_{\mathrm{CWC}-\mathrm{sw}}$ and partition coefficient $\mathrm{D}_{\mathrm{CWC} / \mathrm{Sw}}(\mathrm{Ba})$ are largely due to measurement uncertainty, rather than systematic biases within the data set. Furthermore, the level of uncertainty is small relative to the observed geographical variation in the modern ocean (Fig. 2), supporting the strength of coupling $\mathrm{Ba} / \mathrm{Ca}$ and $\mathrm{Ba}$ isotope measurements on CWCs to provide novel assessment of the past Ba cycle in the past.

This approach might be used to trace changes in nutrient cycling, upwelling, and water-mass circulation (Bates et al., 2017; Bridgestock et al., 2018; Horner et al., 2015). Changes in the general relationship of $\delta^{138 / 134} \mathrm{Ba}$ and $[\mathrm{Ba}]$ in the past might also be used to identify whole-ocean changes in the Ba-cycle and deviations from the relationship used to assess inputs in the past ocean (e.g. from rivers or in the deep ocean) (Cao et al., 2016; Hsieh and Henderson, 2017).

\section{Conclusions}

Barium isotopes $\left(\delta^{138 / 134} \mathrm{Ba}\right)$ in eight different taxa of colonial and solitary aragonitic scleractinian coldwater corals (CWC), taken from sites in the North Atlantic, the Equatorial Atlantic, and the Drake Passage, show a surprisingly constant isotope offset towards lighter values with a mean of $\varepsilon_{\mathrm{Ba}} \approx$ $\Delta^{138 / 134} \mathrm{Ba}$ CwC-sw $=-0.21 \pm 0.08 \%$. Within this reproducibility no relationship with species or location and the environmental variables dissolved $\mathrm{Ba}$ concentration, depth, temperature, salinity, $\mathrm{pH}$ or phosphate concentration is observed. The mean partition coefficient for $\mathrm{Ba}\left(\mathrm{D}_{\mathrm{CwC} / \mathrm{sw}}(\mathrm{Ba})=1.8 \pm 0.4\right)$ is within the range found in previous studies, regardless of the growth environment. The constancy of 
elemental partitioning and isotope fractionation indicate that coupled $[\mathrm{Ba}]$ and $\delta^{138 / 134} \mathrm{Ba}$ analysis in

CWCs can be used to reconstruct changes in the local and global relationship between [Ba] and

394

395

396

397

398

$\delta^{138 / 134} \mathrm{Ba}$. New information about inputs of $\mathrm{Ba}$ to the ocean, and the past global oceanic cycling of Ba, might thus be gained and past changes in riverine and hydrothermal inputs to the ocean assessed.

\section{Acknowledgements}

The authors would like to thank three anonymous reviewers for their helpful and constructive comments that greatly improved this manuscript. We would also like to thank the cruise members of Nathaniel B. Palmer cruise NB1103, James Cook Cruise JC094 and the N/O Thalassa cruise ICE CTD for their assistance in retrieving the samples we worked on. We thank Tristan Horner and Stephanie Bates for the early provision of the Equatorial Atlantic seawater data. This project was supported by the European Research Council (ERC) for funding to LFR and the Deutscher Akademischer Austauschdienst (DAAD) and Heidelberg Graduate School for Fundamental Physics (HGSFP), who funded FH position during the time of this project.

\section{References}

Adkins, J.F., Boyle, E.A., Curry, W.B., and Lutringer, A. (2003). Stable isotopes in deep-sea corals and a new mechanism for "vital effects." Geochim. Cosmochim. Acta 67, 1129-1143.

von Allmen, K., Böttcher, M.E., Samankassou, E., and Nägler, T.F. (2010). Barium isotope fractionation in the global barium cycle: First evidence from barium minerals and precipitation experiments. Chem. Geol. 277, 70-77.

Anagnostou, E., Sherrell, R.M., Gagnon, A., LaVigne, M., Field, M.P., and McDonough, W.F. (2011). Seawater nutrient and carbonate ion concentrations recorded as $\mathrm{P} / \mathrm{Ca}, \mathrm{Ba} / \mathrm{Ca}$, and $\mathrm{U} / \mathrm{Ca}$ in the deepsea coral Desmophyllum dianthus. Geochim. Cosmochim. Acta 75, 2529-2543.

Bates, S.L., Hendry, K.R., Pryer, H.V., Kinsley, C.W., Pyle, K.M., Woodward, E.M.S., and Horner, T.J. (2017). Barium isotopes reveal role of ocean circulation on barium cycling in the Atlantic. Geochim. Cosmochim. Acta.

Bishop, J.K.B. (1988). The barite-opal-organic carbon association in oceanic particulate matter. Nature 332, 341-343.

Böhm, F., Gussone, N., Eisenhauer, A., Dullo, W.-C., Reynaud, S., and Paytan, A. (2006). Calcium isotope fractionation in modern scleractinian corals. Geochim. Cosmochim. Acta 70, 4452-4462. 
Böttcher, M.E., Geprägs, P., Neubert, N., von Allmen, K., Pretet, C., Samankassou, E., and Nägler, T.F. (2012). Barium isotope fractionation during experimental formation of the double carbonate $\mathrm{BaMn}\left[\mathrm{CO}_{3}\right]_{2}$ at ambient temperature. Isotopes Environ. Health Stud. 48, 457-463.

Bridgestock, L., Hsieh, Y.-T., Porcelli, D., Homoky, W.B., Bryan, A., and Henderson, G.M. (2018). Controls on the barium isotope compositions of marine sediments. Earth Planet. Sci. Lett. 481, 101110.

Bullen, T., and Chadwick, O. (2016). Ca, Sr and Ba stable isotopes reveal the fate of soil nutrients along a tropical climosequence in Hawaii. Chem. Geol. 422, 25-45.

Cao, Z., Siebert, C., Hathorne, E.C., Dai, M., and Frank, M. (2016). Constraining the oceanic barium cycle with stable barium isotopes. Earth Planet. Sci. Lett. 434, 1-9.

Chen, T., Robinson, L.F., Burke, A., Southon, J., Spooner, P., Morris, P.J., and Ng, H.C. (2015).

Synchronous centennial abrupt events in the ocean and atmosphere during the last deglaciation. Science 349, 1537-1541.

Cheng, H., Adkins, J., Edwards, R.L., and Boyle, E.A. (2000). U-Th dating of deep-sea corals. Geochim. Cosmochim. Acta 64, 2401-2416.

Chow, T.J., and Goldberg, E.D. (1960). On the marine geochemistry of barium. Geochim. Cosmochim. Acta 20, 192-198.

Copard, K., Colin, C., Douville, E., Freiwald, A., Gudmundsson, G., De Mol, B., and Frank, N. (2010). Nd isotopes in deep-sea corals in the North-eastern Atlantic. Quat. Sci. Rev. 29, 2499-2508.

Dehairs, F., Chesselet, R., and Jedwab, J. (1980). Discrete suspended particles of barite and the barium cycle in the open ocean. Earth Planet. Sci. Lett. 49, 528-550.

DePaolo, D.J. (2004). Calcium isotopic variations produced by biological, kinetic, radiogenic and nucleosynthetic processes. Chapter Rev. Mineral. Geochem. 55, 255-288.

Douville, E., Sallé, E., Frank, N., Eisele, M., Pons-Branchu, E., and Ayrault, S. (2010). Rapid and accurate $\mathrm{U}$-Th dating of ancient carbonates using inductively coupled plasma-quadrupole mass spectrometry. Chem. Geol. 272, 1-11.

Fantle, M.S., and DePaolo, D.J. (2007). Ca isotopes in carbonate sediment and pore fluid from ODP Site 807A: The $\mathrm{Ca} 2+(\mathrm{aq})$-calcite equilibrium fractionation factor and calcite recrystallization rates in Pleistocene sediments. Geochim. Cosmochim. Acta 71, 2524-2546.

Fietzke, J., and Eisenhauer, A. (2006). Determination of temperature-dependent stable strontium isotope ( ${ }^{88} \mathrm{Sr} /{ }^{86} \mathrm{Sr}$ ) fractionation via bracketing standard MC-ICP-MS: SR ISOTOPE FRACTIONATION. Geochem. Geophys. Geosystems 7, n/a-n/a.

Foster, D.A., Staubwasser, M., and Henderson, G.M. (2004). 226Ra and Ba concentrations in the Ross Sea measured with multicollector ICP mass spectrometry. Mar. Chem. 87, 59-71.

Frank, N., Montagna, P., Arnaud-Haond, and \& the ICECTD shipboard scientists (2012). Cruise Report ICECTD, Brest (FR) - Reykjavik (IS) - Ponta Delgada (PO), 11 June - 07 July 2012. 
Gass, S.E., and Roberts, J.M. (2006). The occurrence of the cold-water coral Lophelia pertusa (Scleractinia) on oil and gas platforms in the North Sea: Colony growth, recruitment and environmental controls on distribution. Mar. Pollut. Bull. 52, 549-559.

Hathorne, E.C., Gagnon, A., Felis, T., Adkins, J., Asami, R., Boer, W., Caillon, N., Case, D., Cobb, K.M., Douville, E., et al. (2013). Interlaboratory study for coral Sr/Ca and other element/Ca ratio measurements. Geochem. Geophys. Geosystems 14, 3730-3750.

Henderson, P., and Henderson, Gideon M. (2009). The Cambridge Handbook of Earth Science Data (New York: Cambridge University Press).

Horner, T.J., Kinsley, C.W., and Nielsen, S.G. (2015). Barium-isotopic fractionation in seawater mediated by barite cycling and oceanic circulation. Earth Planet. Sci. Lett. 430, 511-522.

Horner, T.J., Pryer, H.V., Nielsen, S.G., Crockford, P.W., Gauglitz, J.M., Wing, B.A., and Ricketts, R.D. (2017). Pelagic barite precipitation at micromolar ambient sulfate. Nat. Commun. 8, 1342.

Hsieh, Y.-T., and Henderson, G.M. (2017). Barium stable isotopes in the global ocean: Tracer of Ba inputs and utilization. Earth Planet. Sci. Lett.

Jeandel, C., Dupré, B., Lebaron, G., Monnin, C., and Minster, J.-F. (1996). Longitudinal distributions of dissolved barium, silica and alkalinity in the western and southern Indian Ocean. Deep Sea Res. Part Oceanogr. Res. Pap. 43, 1-31.

LaVigne, M., Hill, T.M., Spero, H.J., and Guilderson, T.P. (2011). Bamboo coral Ba/Ca: Calibration of a new deep ocean refractory nutrient proxy. Earth Planet. Sci. Lett. 312, 506-515.

LaVigne, M., Grottoli, A.G., Palardy, J.E., and Sherrell, R.M. (2016). Multi-colony calibrations of coral $\mathrm{Ba} / \mathrm{Ca}$ with a contemporaneous in situ seawater barium record. Geochim. Cosmochim. Acta 179, 203-216.

Lea, D.W., and Boyle, E.A. (1993). Determination of carbonate-bound barium in foraminifera and corals by isotope dilution plasma-mass spectrometry. Chem. Geol. 103, 73-84.

Mangini, A., Lomitschka, M., Eichstadter, R., Frank, N., Vogler, S., Bonani, G., Hajdas, I., and Patzold, J. (1998). Coral provides way to age deep water. Nature 392, 347-348.

Margolin, A.R., Robinson, L.F., Burke, A., Waller, R.G., Scanlon, K.M., Roberts, M.L., Auro, M.E., and van de Flierdt, T. (2014). Temporal and spatial distributions of cold-water corals in the Drake Passage: Insights from the last 35,000 years. Deep Sea Res. Part II Top. Stud. Oceanogr. 99, 237-248.

Marriott, C.S., Henderson, G.M., Belshaw, N.S., and Tudhope, A.W. (2004). Temperature dependence of $\delta 7 \mathrm{Li}, 844 \mathrm{Ca}$ and $\mathrm{Li} / \mathrm{Ca}$ during growth of calcium carbonate. Earth Planet. Sci. Lett. 222, 615-624.

Mavromatis, V., van Zuilen, K., Purgstaller, B., Baldermann, A., Nägler, T.F., and Dietzel, M. (2016). Barium isotope fractionation during witherite ( $\mathrm{BaCO} 3$ ) dissolution, precipitation and at equilibrium. Geochim. Cosmochim. Acta 190, 72-84.

Miyazaki, T., Kimura, J.-I., and Chang, Q. (2014). Analysis of stable isotope ratios of Ba by doublespike standard-sample bracketing using multiple-collector inductively coupled plasma mass spectrometry. J. Anal. At. Spectrom. 29, 483. 
Monnin, C., Jeandel, C., Cattaldo, T., and Dehairs, F. (1999). The marine barite saturation state of the world's oceans. Mar. Chem. 65, 253-261.

Mortensen, P.B. (2001). Aquarium observations on the deep-water coral Lophelia pertusa (L., 1758) (scleractinia) and selected associated invertebrates. Ophelia 54, 83-104.

Nan, X., Wu, F., Zhang, Z., Hou, Z., Huang, F., and Yu, H. (2015). High-precision barium isotope measurements by MC-ICP-MS. J Anal Spectrom 30, 2307-2315.

Okai, T., Suzuki, A., Kawahata, H., Terashima, S., and Imai, N. (2002). Preparation of a New Geological Survey of Japan Geochemical Reference Material: Coral JCp-1. Geostand. NewsI. 26, 95-99.

Orejas, C., Gori, A., and Gili, J.M. (2008). Growth rates of live Lophelia pertusa and Madrepora oculata from the Mediterranean Sea maintained in aquaria. Coral Reefs 27, 255-255.

Paytan, A., and Griffith, E.M. (2007). Marine barite: Recorder of variations in ocean export productivity. Deep Sea Res. Part II Top. Stud. Oceanogr. 54, 687-705.

Pretet, C., van Zuilen, K., Nägler, T.F., Reynaud, S., Böttcher, M.E., and Samankassou, E. (2016). Constraints on barium isotope fractionation during aragonite precipitation by corals. Depositional Rec. 1, 118-129.

Raddatz, J., Liebetrau, V., Rüggeberg, A., Hathorne, E., Krabbenhöft, A., Eisenhauer, A., Böhm, F., Vollstaedt, H., Fietzke, J., López Correa, M., et al. (2013). Stable Sr-isotope, Sr/Ca, Mg/Ca, Li/Ca and $\mathrm{Mg} / \mathrm{Li}$ ratios in the scleractinian cold-water coral Lophelia pertusa. Chem. Geol. 352, 143-152.

Raddatz, J., Liebetrau, V., Trotter, J., Rüggeberg, A., Flögel, S., Dullo, W.-C., Eisenhauer, A., Voigt, S., and McCulloch, M. (2016). Environmental constraints on Holocene cold-water coral reef growth off Norway: Insights from a multiproxy approach. Paleoceanography 31, 2016 PA002974.

Roberts, J.M., Wheeler, A.J., and Freiwald, A. (2006). Reefs of the Deep: The Biology and Geology of Cold-Water Coral Ecosystems. Science 312, 543-547.

Roberts, J.M., Wheeler, A.J., Freiwald, A., and Cairns, S.D. (2009). Cold-Water Corals - The Biology and Geology of Deep-Sea Coral Habitats (Cambridge University Press).

Robinson, L.F. (2014). RRS James Cook Cruise JC094, October 13-November 30 2013, TenerifeTrinidad. TROPICS, Tracing Oceanic Processes using Corals and Sediments. Reconstructing abrupt Changes in Chemistry and Circulation of the Equatorial Atlantic Ocean: Implications for global Climate and deep-water Habitats.

Robinson, L.F., and Waller, R.G. (2011). Historic perspectives on climate and biogeography from deep-sea corals in the Drake Passage.' Cruise report RVIB Nathaniel B Palmer Cruise 11-03, May 09June 2011.

Robinson, L.F., Adkins, J.F., Frank, N., Gagnon, A.C., Prouty, N.G., Brendan Roark, E., and de Flierdt, T. van (2014). The geochemistry of deep-sea coral skeletons: A review of vital effects and applications for palaeoceanography. Deep Sea Res. Part II Top. Stud. Oceanogr. 99, 184-198.

Rollion-Bard, C., Vigier, N., Meibom, A., Blamart, D., Reynaud, S., Rodolfo-Metalpa, R., Martin, S., and Gattuso, J.-P. (2009). Effect of environmental conditions and skeletal ultrastructure on the Li isotopic composition of scleractinian corals. Earth Planet. Sci. Lett. 286, 63-70. 
535 Spooner, P.T. (2016). Investigating the use of Cold-Water Corals as Archives of Past Ocean Water 536 Properties. University of Bristol.

537 Spooner, P.T., Guo, W., Robinson, L.F., Thiagarajan, N., Hendry, K.R., Rosenheim, B.E., and Leng, M.J. 538 (2016). Clumped isotope composition of cold-water corals: A role for vital effects? Geochim.

539 Cosmochim. Acta 179, 123-141.

540 Wolgemuth, K., and Broecker, W.S. (1970). Barium in sea water. Earth Planet. Sci. Lett. 8, 372-378.

541 Yoshimura, T., Tanimizu, M., Inoue, M., Suzuki, A., Iwasaki, N., and Kawahata, H. (2011). Mg isotope 542 fractionation in biogenic carbonates of deep-sea coral, benthic foraminifera, and hermatypic coral.

543 Anal. Bioanal. Chem. 401, 2755-2769.

544 van Zuilen, K., Müller, T., Nägler, T.F., Dietzel, M., and Küsters, T. (2016). Experimental determination 545 of barium isotope fractionation during diffusion and adsorption processes at low temperatures.

546 Geochim. Cosmochim. Acta 186, 226-241.

547 


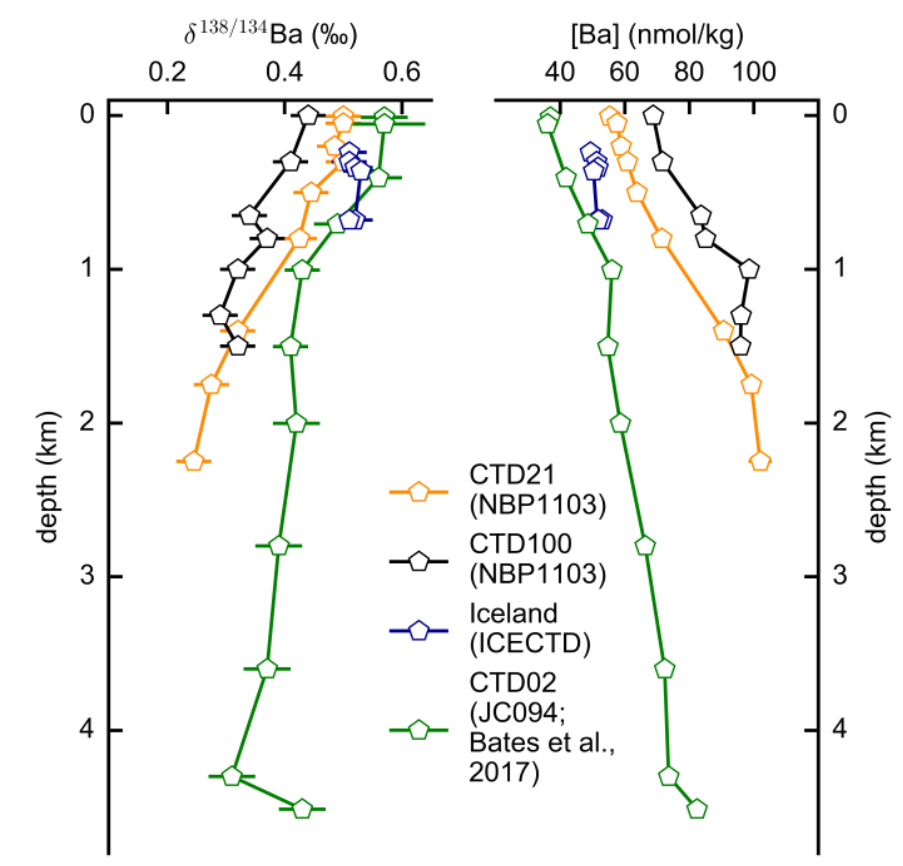

551

Figure 1

553

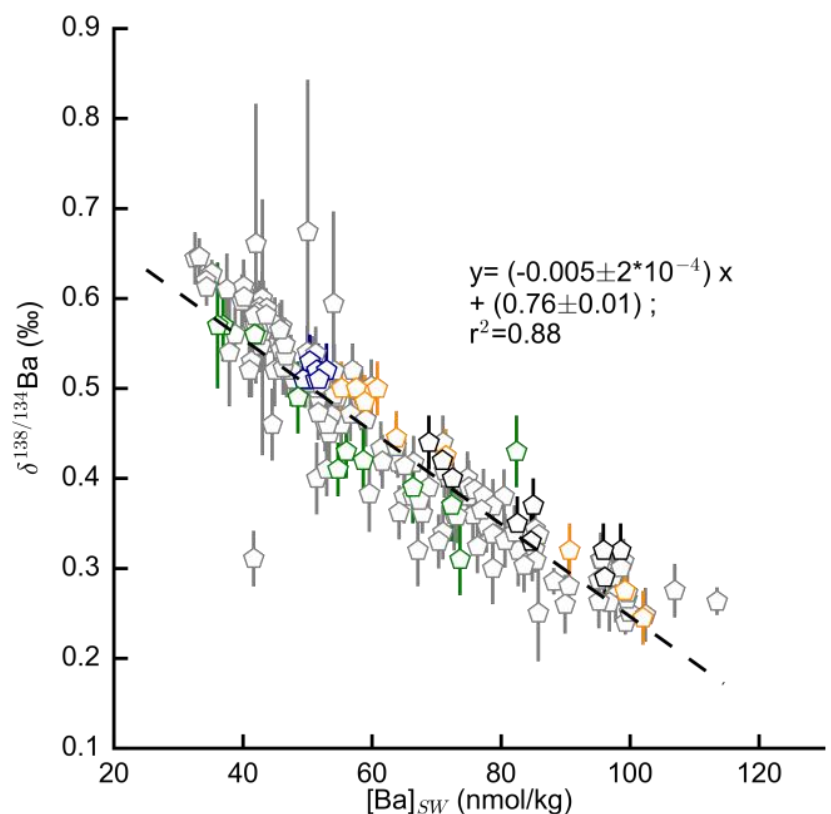

$\begin{array}{llll}\$ & \text { published SW data } & \$ & \text { CTD100 (NBP1103) } \\ \vdots & \text { CTD21 (NBP1103) } & \$ & \text { CTD02 (JC094; Bates } \\ \text { Iceland (ICECETD) } & \$ & \text { et al., 2017) }\end{array}$




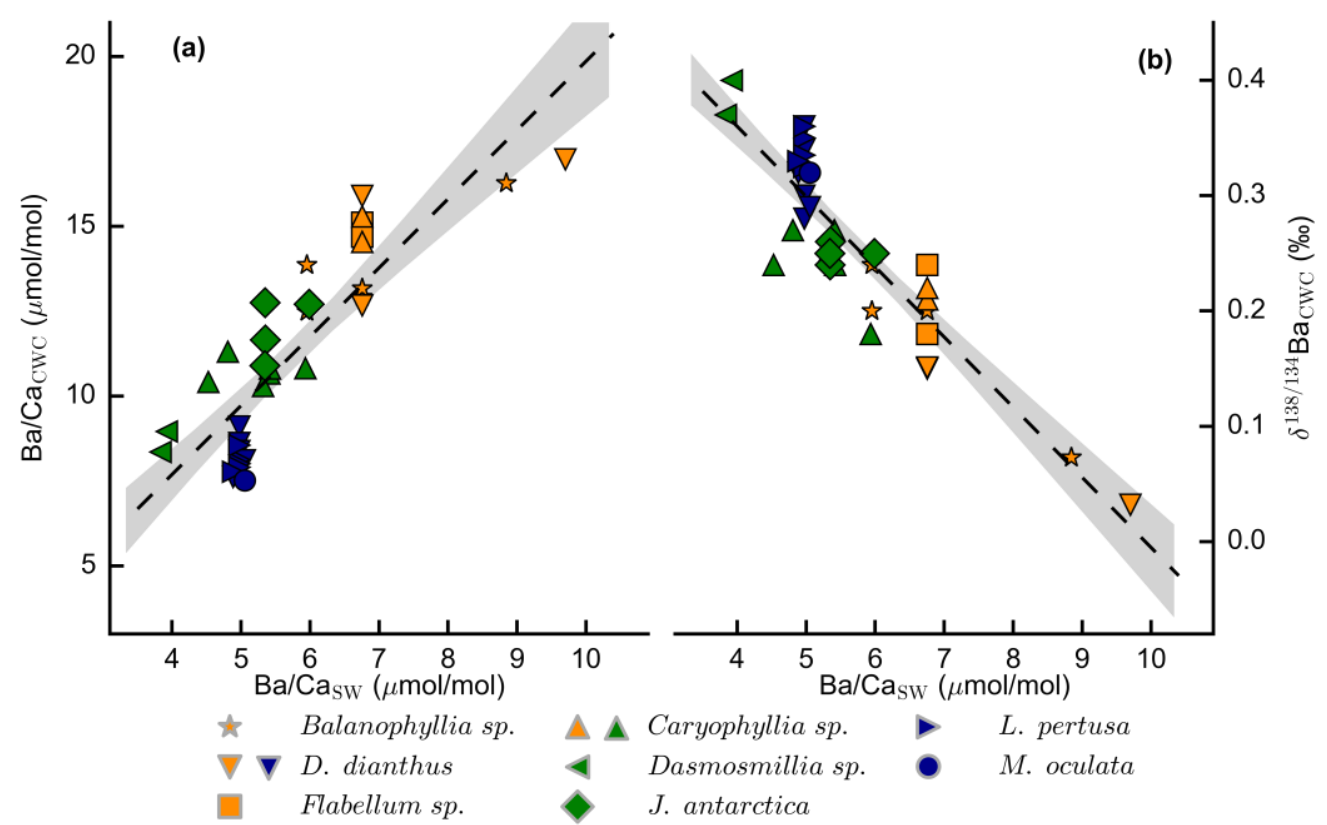

556

Drake Passage

EQ Atlantic

North Atlantic

Figure 3 
Burdwood Bank

(Drake Passage)

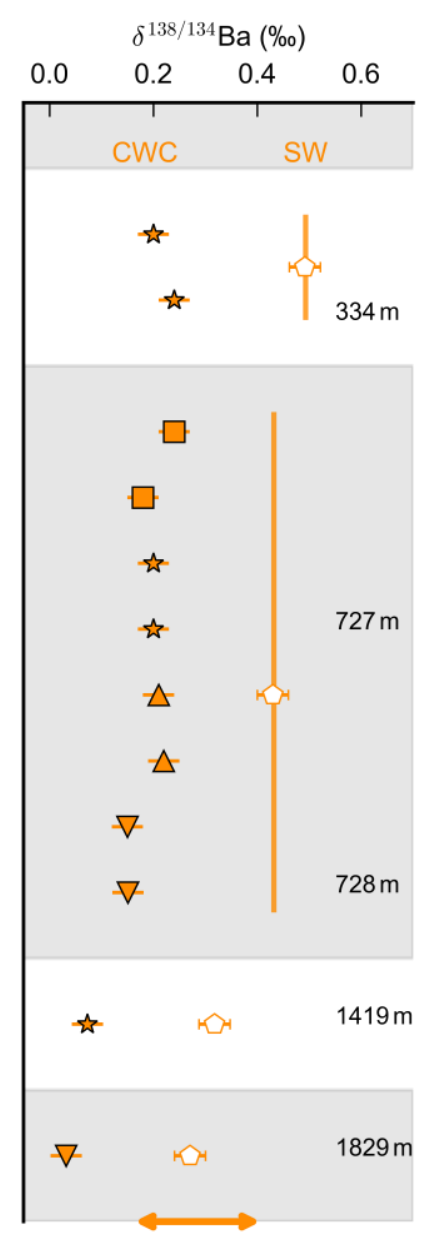

$\Delta^{138 / 134} \mathrm{Ba}_{\mathrm{CWC}-\mathrm{SW}}$

$\approx-0.24 \pm 0.06 \%$

+ Balanophyllia sp.

$\nabla \nabla$ D. dianthus

Flabellum sp.
Carter Seamount

(EQ Atlantic)

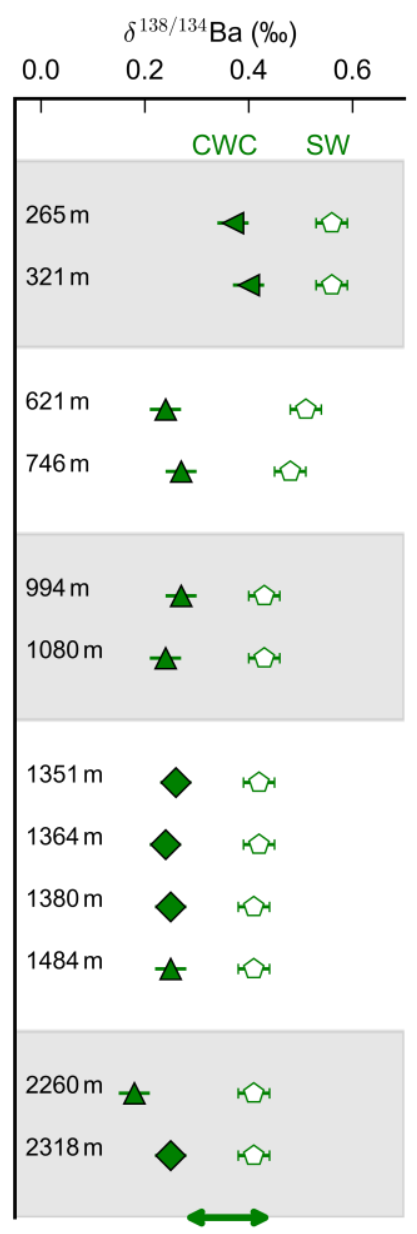

$\Delta^{138 / 134} \mathrm{Ba}_{\mathrm{CWC}-\mathrm{SW}}$ $\approx-0.19 \pm 0.07 \%$ o

\. Caryophyllia sp. Dasmosmillia sp.
Iceland

(North Atlantic)

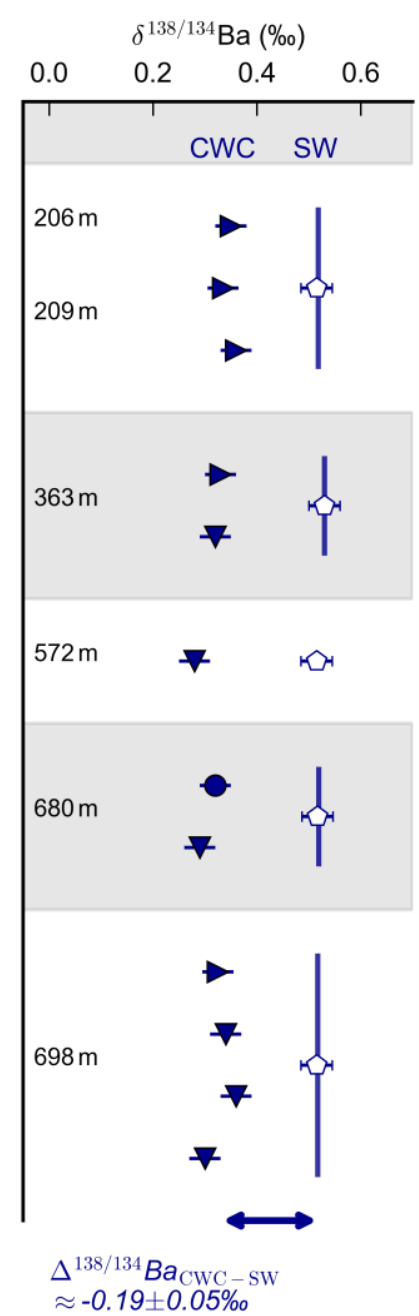

$\Delta^{138 / 134} \mathrm{Ba}_{\mathrm{CWC}-\mathrm{SW}}$
$\approx-0.19 \pm 0.05 \% \circ$
J. antarctica

L. pertusa
M. oculata extrapolated Seawater 


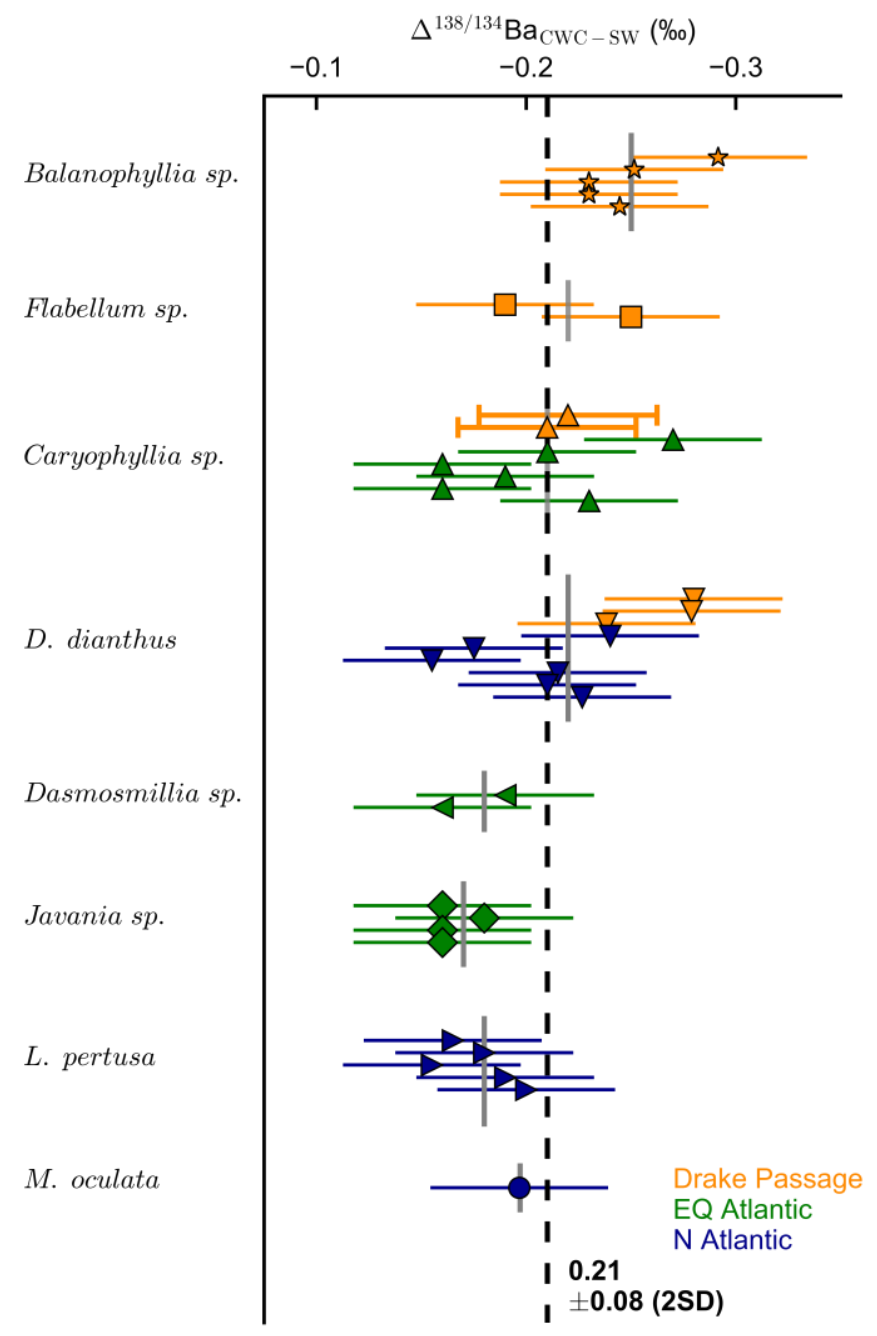

560

561 Figure 5

562

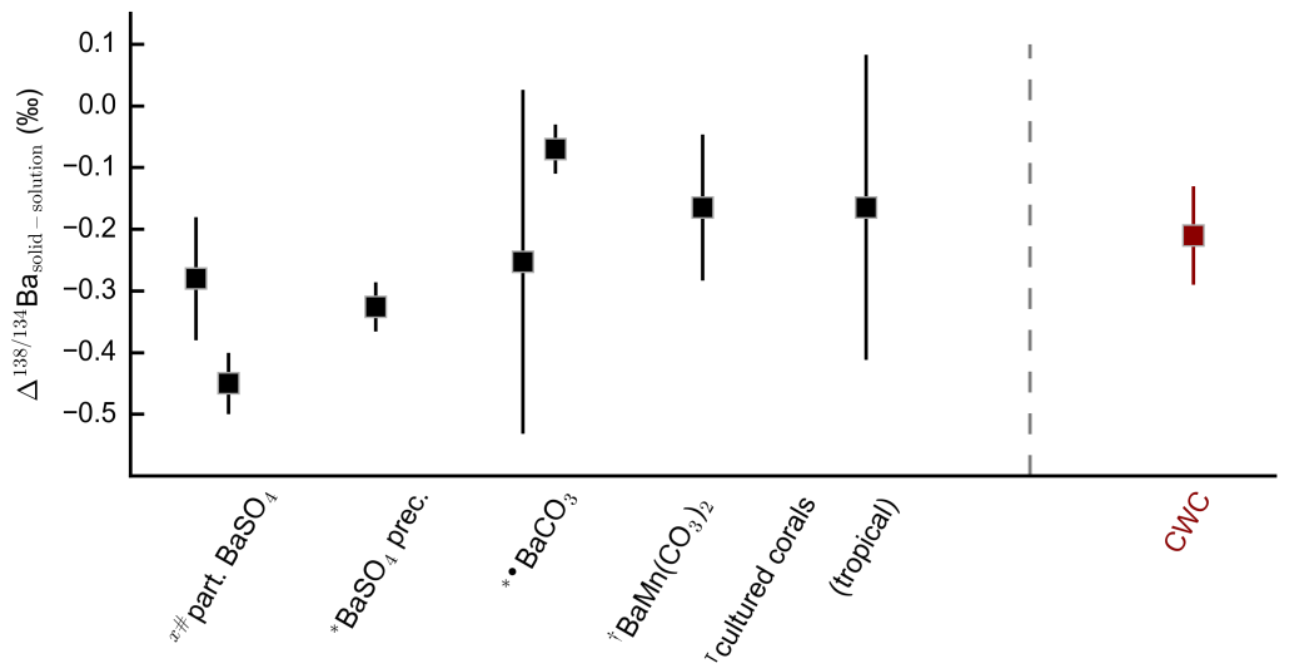

Figure 6 

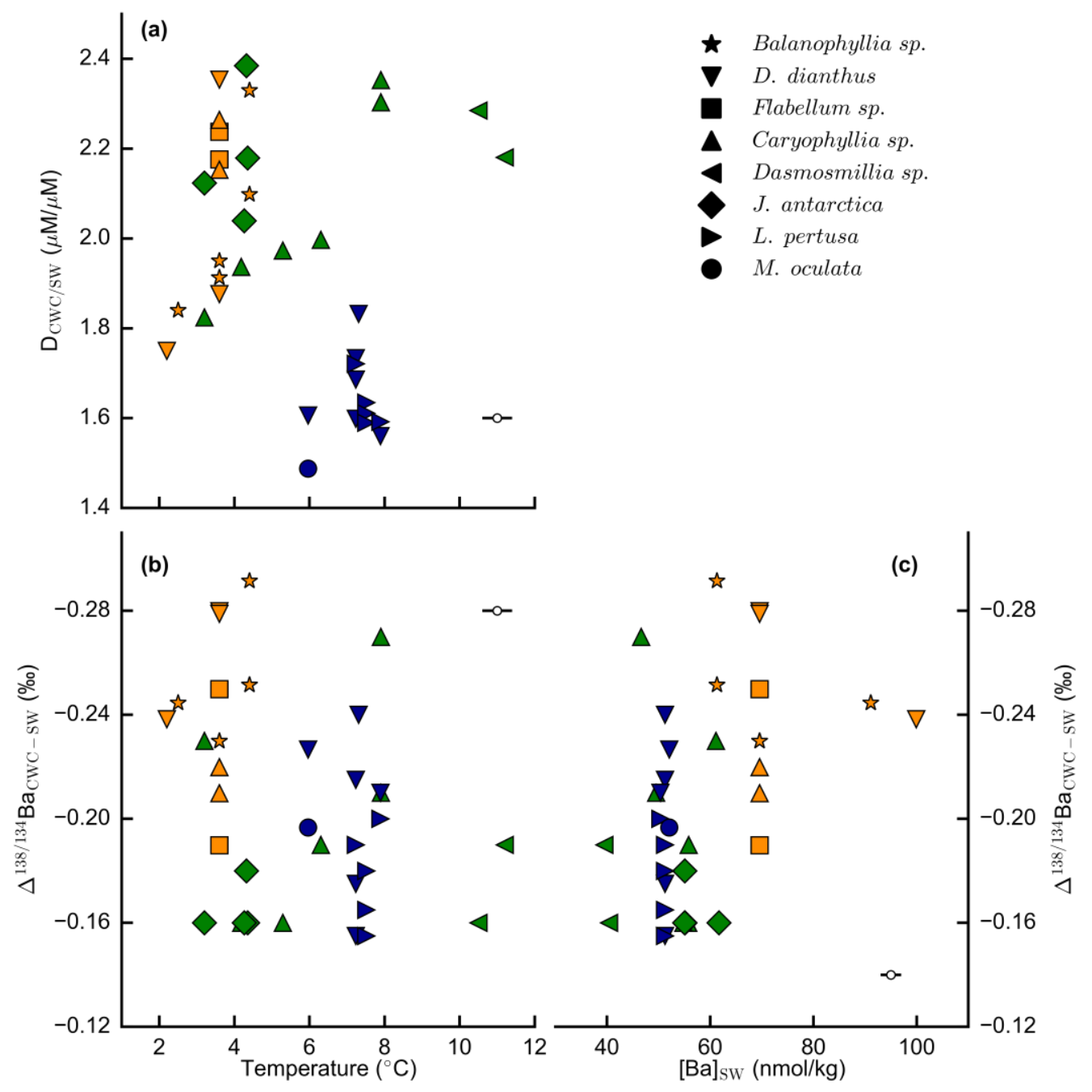


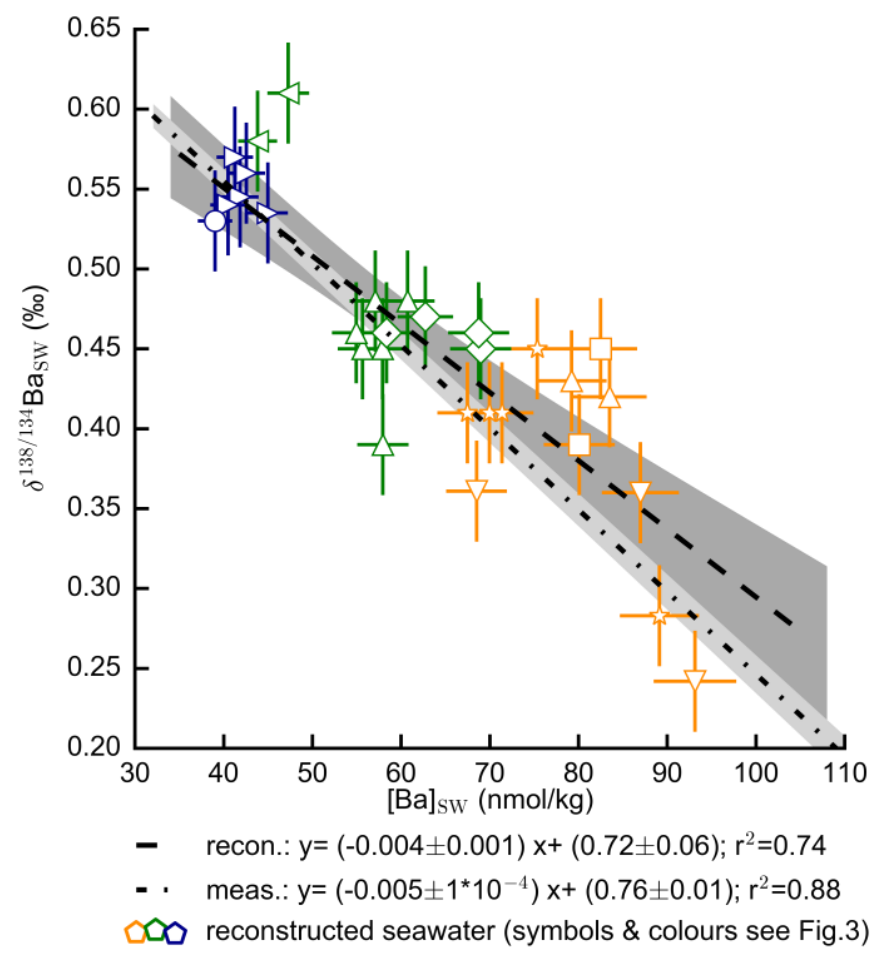

Figure 8

569

570

Table 1

\begin{tabular}{|l|l|l|l|l|}
\hline station & latitude & longitude & covered depths & analysed depths \\
& & & & \\
\hline & & & & \\
\hline Iceland & & & \\
\hline Hafadjup CWC & $63^{\circ} 16.82^{\prime}-63^{\circ} 20.52^{\prime} \mathrm{N}$ & $19^{\circ} 34.11^{\prime}-19^{\circ} 35.75^{\prime} \mathrm{W}$ & $363-680$ & $363-680$ \\
\hline Hafadjup SW & $63^{\circ} 19.02^{\prime} \mathrm{N}$ & $19^{\circ} 36.72^{\prime} \mathrm{W}$ & $360-680$ & $360-680$ \\
\hline Reykjanes Ridge CWC & $62^{\circ} 36.45^{\prime}-63^{\circ} 5.13^{\prime} \mathrm{N}$ & $24^{\circ} 59.27^{\prime}-24^{\circ} 32.53^{\prime} \mathrm{W}$ & $209-698$ & $209-698$ \\
\hline Reykjanes Ridge SW & $62^{\circ} 53.34^{\prime} \mathrm{N}$ & $24^{\circ} 50.88^{\prime} \mathrm{W}$ & $238-338$ & $238-338$ \\
\hline Equatorial Atlantic & & & & \\
\hline Carter Seamount CWC & $5^{\circ} 36.66^{\prime}-9^{\circ} 13.37^{\prime} \mathrm{N}$ & $21^{\circ} 16.49^{\prime}-26^{\circ} 57.46^{\prime} \mathrm{W}$ & $265-2318$ & $265-2318$ \\
\hline JC094 CTD 2 SW & $9^{\circ} 17.1^{\prime} \mathrm{N}$ & $21^{\circ} 38.0^{\prime} \mathrm{W}$ & $0-4524$ & $0-4524$ \\
\hline Drake Passage & & & & \\
\hline Burdwood Bank & $54^{\circ} 50.26^{\prime}-54^{\circ} 50.33^{\prime} \mathrm{S}$ & $62^{\circ} 7.11^{\prime}-62^{\circ} 14.99^{\prime} \mathrm{W}$ & $334-1829$ & $334-1829$ \\
\hline NBP1103 CTD 21 & $55^{\circ} 3.25^{\prime} \mathrm{S}$ & $62^{\circ} 81^{\prime} \mathrm{W}$ & $0-4110$ & $0-2250$ \\
\hline NBP1103 CTD 100 & $60^{\circ} 33.85^{\prime} \mathrm{S}$ & $65^{\circ} 29.57^{\prime} \mathrm{W}$ & $0-3100$ & $0-1500$ \\
\hline
\end{tabular}




\section{Figure and table captions}

573

574

575

576

577

578

579

580

581

582

583

584

585

586

587

588

589

590

591

592

593

594

595

596

597

598

599

Figure 1:

Seawater profiles for dissolved $\mathrm{Ba}$ concentrations [Ba] and $\mathrm{Ba}$ isotope compositions $\delta^{138 / 134} \mathrm{Ba}$. At all locations, station CTD21 (Burdwood Bank, orange), CTD100 (Sars Seamount, black), Iceland (Reykjanes Ridge and Hafadjup, blue), and CTD02 (Carter Seamount) (Bates et al., 2017), the wellestablished anti-correlation between $[\mathrm{Ba}]$ and $\delta^{138 / 134} \mathrm{Ba}$ can be observed. Both profiles from cruise NBP1103 reach deeper, but were not analysed in abyssal depths as only depths with coral growth were considered for this study. Station CTD100 will not be discussed further as corals from Sars seamount were not analysed here.

Figure 2:

$\delta^{138 / 134} \mathrm{Ba}_{\mathrm{sw}}$ against $[\mathrm{Ba}]_{\mathrm{Sw}}$ for samples from this study and published data (Bridgestock et al., 2018; Hsieh and Henderson, 2017; Bates et al., 2017; Pretet et al., 2016; Horner et al., 2015). Data from Bates et al. (2017) were used in this study for considerations of corals from the Equatorial Atlantic (green symbols). Cao et al. (2016) data were not included in this summary as their seawater samples exhibited a different correlation with higher $\mathrm{Ba}$ isotope compositions. Our data agree well with the other studies. Note that seawater Ba isotope composition at the coral sites cover nearly the total observed range of $\delta^{138 / 134} \mathrm{Ba}$ reported in the other studies.

\section{Figure 3:}

$\mathrm{Ba} / \mathrm{Ca}$ in $\mathrm{CWCs}$ and ambient seawater (a) and seawater $\mathrm{Ba} / \mathrm{Ca}$ sw influence on coralline $\delta^{138 / 134} \mathrm{Ba}(\mathrm{b})$. (a) A linear fit (black dashed line) through the data gives: $\mathrm{Ba} / \mathrm{Ca}_{\mathrm{cwC}}=1.8( \pm 0.4) \mathrm{Ba} / \mathrm{Ca}$ sw $+0.7( \pm 2.6)$ with a correlation factor of $\mathrm{r}^{2}=0.67$ ( 0.95 confidence interval as shaded grey area).

(b) Similar to seawater $\delta^{138 / 134} \mathrm{Ba}$, a close anti-correlation to Ba concentration (here as $\mathrm{Ba} / \mathrm{Casw}$ ) can be observed for coralline $\delta^{138 / 134} \mathrm{Ba}$. The correlation factor $\mathrm{r}^{2}$ is 0.82 .

Figure 4: 
600

601

602

603

604

605

606

607

608

609

610

611

612

613

614

615

616

617

618

619

620

621

622

623

624

625

626

$\delta^{138 / 134} \mathrm{Ba}$ in CWCs (filled symbols) at all three sites compared to ambient seawater (open symbols).

Seawater values are extrapolated to the depth each coral grew at. All CWCs are isotopically lighter than ambient seawater, with higher $\mathrm{Ba}$ isotope compositions in shallower depths than in deeper waters. Within uncertainties all sites show a similar mean fractionation. The overall fractionation of Burdwood Bank corals is $\Delta^{138 / 134} \mathrm{Bacwc-sw}=-0.24 \pm 0.06 \%$, while Carter Seamount and Iceland corals both fractionate Ba by $-0.19 \%$ with a $2 \mathrm{SD}$ of $\pm 0.07 \%$ and $\pm 0.05 \%$ respectively.

\section{Figure 5:}

$\Delta^{138 / 134} \mathrm{Bacwc}$ for each species/ genus separately.

The overall fractionation between corals and seawater is $\Delta^{138 / 134} \mathrm{Ba}_{\mathrm{CwC}}=-0.21 \pm 0.08 \%$ ( $2 \mathrm{SD}$ and $0.01 \%$ $\mathrm{SE})$. The maximum species specific fractionation is $\Delta^{138 / 134} \mathrm{Ba} \mathrm{CwC}=-0.25 \pm 0.05 \%$ for Balanophyllia sp. and the minimum $\Delta^{138 / 134} \mathrm{Ba}_{\mathrm{CwC}}=-0.17 \pm 0.04 \%$ for Javania $s p$. (uncertainties are the larger of external reproducibility and $2 \mathrm{SD}$ from averaging). The species $D$. dianthus shows the largest variability in $\Delta^{138 / 134} \mathrm{Ba}_{\mathrm{CWC}}$, ranging from -0.16 to $-0.28 \%$ and an average of $-0.22 \pm 0.08 \%$.

Figure 6:

Comparison of $\Delta^{138 / 134} \mathrm{Ba}$ to published assessments. Particulate ${ }^{\# x} \mathrm{BaSO}_{4}$ (part.) were estimated by Horner et al., 2015, ${ }^{\mathrm{x}} \mathrm{BaSO}_{4}$ (part.) by Bridgestock et al., 2018 and Horner et al., 2017, precipitates of $* \mathrm{BaSO}_{4}$ (prec.) and $* \mathrm{BaCO}_{3}$ were analysed by von Allmen et al., 2010 , of ${ }^{*} \mathrm{BaCO}_{3}$ by Mavromatis et al., 2016, of ${ }^{\dagger} \mathrm{BaMn}\left[\mathrm{CO}_{3}\right]_{2}$ by Böttcher et al., 2012 and ${ }^{\top}$ cultured tropical corals were investigated by Pretet et al., 2016. Uncertainties are 2SE for repeat analysis of one sample.

The variation seen in precipitates is larger than for all thirty-six natural CWCs investigated in this study (red). CWCs are separately analysed for location and species in Fig. 4 and 5.

\section{Figure 7:}

Temperature dependency of $\mathrm{D}_{\mathrm{CwC} / \mathrm{sw}}$ (a) and $\Delta^{138 / 134} \mathrm{BaCwC}(\mathrm{b})$, and correlation between $[\mathrm{Ba}]_{\mathrm{sw}}$ and $\Delta^{138 / 134} \mathrm{Ba}_{\mathrm{CwC}}(\mathrm{c})$. No correlation of $\mathrm{D}_{\mathrm{CwC} / \mathrm{sw}}$ with temperature $\left(\mathrm{r}^{2}=0.02\right)$ and $\Delta^{138 / 134} \mathrm{Ba}_{\mathrm{CwC}}$ with 
627 temperature $\left(\mathrm{r}^{2}=0.12\right)$ and $[\mathrm{Ba}]_{\mathrm{Sw}}\left(\mathrm{r}^{2}=0.16\right)$ can be observed (for colours see e.g. Fig. 4). Uncertainties

628 for temperature and $[\mathrm{Ba}]_{\mathrm{sw}}$ are displayed with the extra open data point.

629

630

631 Figure 8:

632 Comparison between the established seawater [Ba $]_{\mathrm{sw}}$ and $\delta^{138 / 134} \mathrm{Ba}$ correlation (meas.: dash-dot line) 633 and the seawater characteristic 'reconstructed' from the CWCs (reconstructed: dashed line). The 634 reconstruction was achieved by applying a constant partition coefficient and isotope fractionation for 635 Ba to the measured CWC data, obtaining the open coloured symbols (for symbols see e.g. Fig. 3). 636 Uncertainties shown are the external reproducibilities from our measurements. Within uncertainties 637 (grey envelopes) the 'reconstructed' seawater data and $[\mathrm{Ba}]_{\mathrm{sw}}$ and $\delta^{138 / 134} \mathrm{Ba}$ correlation agree with the 638 well-known seawater anti-correlation for $[\mathrm{Ba}]_{s w}$ and $\delta^{138 / 134} \mathrm{Ba}$.

639

640 Table 1:

641 Locations of CWC and seawater sample sites. For the exact coordinates of each cold water coral please 642 refer to the supplementary material. 